\title{
PAWEŁ LISIEWICZ
}

Warszawa

\section{Liberałowie wobec Konstytucji Europejskiej i modelu integracji}

Publiczna debata wokół Konstytucji Europejskiej, stanowiąca apogeum dyskusji na temat dalszej integracji kontynentu zdaje toczyć się między ,euroentuzjastami” popierającymi nowy traktat i sprzeciwiającymi się mu „,eurosceptykami”. W tej debacie liberalna frakcja w Parlamencie Europejskim znajduje się w pierwszym szeregu ,euroentuzjastów”, wspólnie z dwoma największymi frakcjami - socjalistami i chrześcijańskimi demokratami. Po drugiej stronie znajdują się głównie radykalnie prawicowi „eurosceptycy”, czasem w egzotycznym sojuszu ze skrajną lewicą. Ten artykuł prezentuje inną, mniej znaną dyskusję toczącą się w ramach ruchu liberalnego. Konstruktywna krytyka projektu Konwentu Europejskiego „Konstytucji dla Europy” wypływa także z liberalnych środowisk opiniotwórczych, w tym grupy naukowców i think tanków skupionych w European Constitutional Group oraz tygodnika ,The Economist”.

\section{Liberalizm i teoria integracji}

Aby określić podejście (lub możliwe podejścia) liberałów do tego zagadnienia, należy rozważyć różne teoretyczne aspekty relacji między liberalizmem a integracją europejską. Po pierwsze, ponieważ liberalizm jest systemem idei, a integracją - procesem politycznym, należy uwzględnić relacje między wartościami a faktami w polityce. Nie ulega wątpliwości, że między wartościami a faktami w polityce istnieje pewne ,napię-

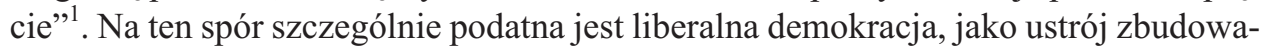
ny na ideach ${ }^{2}$. Pojawia się zatem pytanie, do jakiego stopnia można urzeczywistnić ideały $^{3}$. Należy pamiętać, że idee mogą prowadzić do niespodziewanych skutków, a realne procesy polityczne mogą być inspiracją dla idei ${ }^{4}$. Kluczowe znaczenie w tym zakresie mają pojęcia perfekcjonizmu i realizmu oraz empiryzmu i racjonalizmu. Realizm, związany z anglosaską kulturą empiryczna, kładzie nacisk na fakty ${ }^{5}$. Natomiast perfekcjonizm, bliższy europejskiej kulturze racjonalistycznej, akcentuje rolę wartości. To drugie podejście może powodować konflikt, jeśli zapomni się, że idee ze swojej natury

1 G. Sartori, Teoria demokracji, Warszawa 1994, s. 10.

2 Ibidem, s. 18. Zdaniem Sartoriego demokracja jest szczególnie powiązana ze światem idei. P. Manent, Intelektualna historia liberalizmu, Kraków 1994, s. 7 i 8 . Wg Manenta to samo dotyczy liberalizmu.

3 Ibidem, s. 10.

4 Ibidem, s. 32.

5 Ibidem, s. 28. To jednak także podejścia modelowe. 
nie mogą być w całości wdrożone ${ }^{6}$. Decydujące znaczenie ma więc zrozumienie zasad pośredniczących między ideałami a faktami ${ }^{7}$. Z punktu widzenia efektywności, podmiot działający powinien traktować ideały jak gdyby miały być realizowane, ale z punktu widzenia obserwatora należy sobie zdawać sprawę z fałszywości tego założe$\mathrm{nia}^{8}$. Refleksja ta ma znaczenie zwłaszcza w kontekście różnic między podejściem liberalnych partii i think tanków do zagadnienia Konstytucji Europejskiej.

Po drugie, konieczne jest uwzględnienie różnorodności i typów liberalizmu, w tym podziałów politycznych w jego ramach, różnic geograficznych, etapów rozwoju i przedmiotu oraz „szerokości” pojęcia liberalizmu. Liberalizm socjalny akcentuje wolności osobiste, natomiast w odniesieniu do wolności ekonomicznych widzi potrzebę pewnego zaangażowania państwa w sprawy społeczno-gospodarcze. Liberalizm konserwatywny kładzie nacisk na wolności ekonomiczne, w sprawach światopoglądowych czasami zbliżając się do umiarkowanego konserwatyzmu. Liberalizm klasyczny (amerykański libertarianizm) łączy wiarę w wolność ekonomiczną i osobistą, choć często bardziej koncentruje się na gospodarce. Podział ten wiąże się z etapami rozwoju liberalizmu. Po liberalizmie klasycznym nastapił liberalizm demokratyczny (łącząc założenia klasycznych liberałów z powszechnym prawem wyborczym), a następnie liberalizm socjalny (uwzględniający odpowiedzialność państwa za niektóre problemy społeczne). W ostatnich dziesięcioleciach nastapił powrót do klasycznych źródeł liberalizmu, w postaci libertarianizmu, neoliberalizmu i liberalizmu konserwatywnego. Podziały te pozostają w związku z różnicami geograficznymi. Tradycja angielska, czy też anglosaska liberalizmu związana jest z empiryzmem, stopniowymi i spontanicznymi zmianami i uchodzi za bardziej konserwatywna. Tradycja francuska i kontynentalna jest związana z racjonalizmem oraz rewolucją i inżynierią społeczną, co może czynić ją bardziej lewicową. Paradoksalnie jednak, jeśli chodzi o terminologię, to w USA słowo „liberalizm” oznacza postawę lewicową i socjalliberalną, także w Wielkiej Brytanii liberałowie demokraci reprezentują opcję socjalliberalną, a klasyczni liberałowie (libertarianie) często są bliżsi konserwatystom. Tymczasem w Europie kontynentalnej liberałowie zachowują zazwyczaj pozycje w szerokim centrum. $Z$ przedmiotowego punktu widzenia można wyróżnić liberalizm polityczny, ekonomiczny, społeczny, kulturowy i światopoglądowy. W liberalnych demokracjach za główne zakresy funkcjonowania liberalizmu uważa się kwestie ekonomiczne i światopoglądowe. Choć zdaniem klasycznych liberałów wolność ekonomiczna i osobista są nierozdzielne, czasem liberalizm ekonomiczny bliżej wiązany jest z konserwatyzmem światopoglądowym, a liberalizm światopoglądowy z socjaldemokratycznym podejściem ekonomicznym. Kluczowe znaczenie ma także „szerokość” liberalizmu. W szerszym znaczeniu liberalizm jest powszechną ,ideologią” lub nawet „religią” cywilizacji zachodniej, liberalnej demokracji, praw człowieka. W węższym znaczeniu liberalizm stanowi radykalną obronę wolności ekonomicznej i osobistej, często sytuując się w opozycji do głównych trendów naszej cywilizacji

${ }^{6}$ Ibidem, s. 70-73. Sartori zwraca uwagę na to, że w „racjonalistycznym” języku francuskim używa się pojęcia „lud” i „państwo”, a „empirycznym” angielskim - ludzie i rząd.

7 Ibidem, s. 93.

8 Ibidem, s. 94.

9 D. Tansey, Nauki polityczne, Poznań 1997, s. 114. G. Sartori, Teoria demokracji, Warszawa, 1994, s. 452. Autor dzieli liberalizm na sekciarski i ekumeniczny. Sobolewscy piszą o liberalizmie 
Po trzecie, należy rozważyć podejście liberalizmu do spraw międzynarodowych. W tej dziedzinie wyróżnia się liberalizm republikański, handlowy i regulacyjny oraz liberalizm „od dołu” i „od góry”. Liberalizm republikański zakłada, że liberalna demokracja jest najbardziej pokojowym ustrojem, bo między takimi państwami nie wybuchają wojny. Liberalizm handlowy dowodzi, że wolny rynek i handel prowadzą do pokoju. Liberalizm regulacyjny twierdzi, że współpraca instytucjonalna państw gwarantuje pokój ${ }^{10}$. „Liberalizm od góry”, zwany też neoliberalnym instytucjonalizmem, zakłada budowę liberalnych relacji i instytucji międzynarodowych niezależnie od tego, czy państwa w nich uczestniczące stosują zasady liberalne w polityce wewnętrznej. To podejście może wiązać się z podejściem socjalliberalnym lub nawet socjaldemokratycznym, choć także ekonomią neoklasyczną i teorią public choice. Ta postawa czasem nazywana jest „Keynes at home, Smith abroad” „Liberalizm od dołu” to podejście zakładające, że wolny handel międzynarodowy jest elementem rynkowej polityki gospodarczej (także wewnętrznej) rządów i to państwa prowadzące liberalną politykę wewnętrzną i zewnętrzną, bez większej roli instytucji międzynarodowych, tworzą liberalny porządek międzynarodowy ${ }^{11}$.

Po czwarte, kluczowe jest uwzględnienie modeli spektrum politycznego. Oprócz prostej linii prawica-lewica, na której liberałowie znajdują się w centrum, istnieją bardziej preferowane przez liberałów modele linii liberalizm-totalitaryzm (w tym spektrum kluczowa jest wolność jednostki, a konserwatyzm, chadecja czy socjalizm mieszczą się między liberalizmem a totalitaryzmem), trójkąta (z liberalizmem, konserwatyzmem i socjalizmem jako trzema wierzchołkami) oraz kwadratu (wyznaczonego przez linie wolności ekonomicznej i osobistej) ${ }^{12}$.

Socjalizm (lewica) Liberalizm (centrum) Konserwatyzm (prawica)

Liberalizm Konserwatyzm, Chrześcijańska Demokracja, Socjaldemokracja

Totalitaryzm

(wolność jednostki)

(brak wolności jednostki)

przekraczającym ramy doktryny i liberalizmie ideologicznym po II wojnie światowej. (B. Sobolewska, M. Sobolewski, Myśl polityczna XIX i XX wieku. Liberalizm, Warszawa 1978, s. 138). Po pierwsze, zasady liberalizmu ,przekraczają rangę doktryny”, stając się podstawą ideową Karty Atlantyckiej i Deklaracji Praw Człowieka. Są to jednak zasady zbliżające się do myśli socjalistycznej, konserwatywnej czy chrześcijańsko-demokratycznej (a raczej przez te kierunki przejmowane). Tym ogólnym zasadom brakuje więc wyrazistego ruchu politycznego. Po drugie jednak, odradza się liberalizm nawiązujący do klasycznego etapu swojego rozwoju, łączący rygoryzm wolności politycznej i ekonomicznej.

10 E. Hovden, E. Keene, The globalization of liberalism, New York 2002, s. 16-20.

11 Ibidem, s. 20, 22, 38. R. Sally, Classical liberalism and international order: studies in theory and intellectual history, London-New York 1998, s. 132, 177-179, 184-190, 198.

12 D. Tansey, Nauki polityczne, Poznań 1997, s. 127; F. A. von Hayek, Dlaczego nie jestem konserwatysta, w: Konstytucja wolności, Warszawa 2006, s. 379; www.politopia.com. 


\section{Liberalizm (wolność) \\ Socjaldemokracja (równość) $\bigwedge$ Konserwatyzm (porządek)}

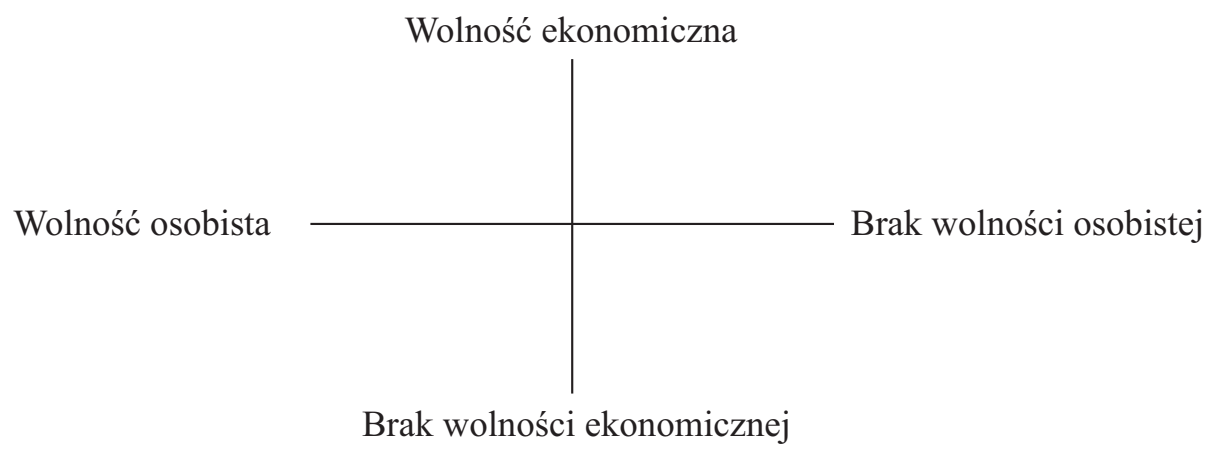

W przeciwieństwie do sceny politycznej, spektrum społeczno-ekonomiczne wydaje się być zdominowane przez dwa tzw. konsensusy: socjaldemokratyczny i neoliberalny. Socjaldemokratyczny, akceptowany jednak także przez większość chrześcijańskich demokratów oraz część liberałów i konserwatystów, dominował w Europie i Ameryce od tzw. Wielkiego Kryzysu (choć jego pierwsze symptomy były widoczne już na przełomie XIX i XX wieku) do lat siedemdziesiątych. Konsensus neoliberalny, symbolizowany przez Margaret Thatcher i Ronalda Reagana (a więc polityków konserwatywnej prawicy), także wpłynął na inne opcje (zwłaszcza ich następców - Tony Blaira i Billa Clintona, ale również np. Wspólnoty Europejskie w zakresie wspólnego rynku ${ }^{13}$.

Po piąte, ponieważ proces integracji europejskiej nie ogranicza się do granic narodowych, należy uwzględnić główne teorie dotyczące relacji między narodami i państwami - nacjonalizmu i kosmopolityzmu oraz teorie stosunków międzynarodowych - realizmu, liberalizmu i marksizmu. Generalnie liberalizm jest przeciwny nacjonalizmowi i łączy się z kosmopolityzmem. Wynika to z liberalnego przekonania o zasadniczym znaczeniu jednostki, a nie narodu, jako grupy jednostek, a także uznania pokoju i wolnego handlu za główne ideały liberałów. Sama idea liberalna jest bez wątpienia ideą uniwersalną. Warto jednak pamiętać, że w XIX wieku tendencje liberalne i narodowe znajdowały się w sojuszu, a sama idea wolności narodowej de facto mogła powstać tylko dzięki podejściu liberalnemu (w konserwatywnej i monarchicznej wizji nie było miejsca na podmiotowość obywateli, a więc także narodów). Istnieją także opinie, że w historii pozycja niektórych narodów (zwłaszcza angielskiego) przyczyniała się do promocji liberalizmu, a dzisiejsza obrona narodów atlantyckich przed islamskimi oznacza także obronę wartości liberalnych. Abstrahując od marksizmu, który wydaje się być mało przydatny dla określenia liberalnego stanowiska w sprawach międzynarodowych, analiza realizmu i liberalizmu ma duże znaczenie dla naszych rozważań. Realizm uważa państwa za główny podmiot stosunków międzynarodowych, opartych na

13 A. Antoszewski, R. Herbut (red.), Demokracje Zachodnioeuropejskie. Analiza porównawcza, Wrocław 1997, s. 54-56. 
sile i jest sceptyczny wobec organizacji międzynarodowych, współpracy i roli idei w tych relacjach. Liberalizm uznaje inne niż państwo podmioty życia międzynarodowego, takie jak organizacje wewnętrzne i międzynarodowe, wierzy w możliwość realizacji idei w sprawach międzynarodowych i kładzie nacisk na relacje ekonomiczne. Co szczególnie istotne, liberalizm jako teoria stosunków międzynarodowych nie pokrywa się z liberalizmem jako filozofią polityczną w sprawach krajowych. Liberalizm międzynarodowy często wiąże się z lewicowymi doktrynami krajowymi, a realizm - z orientacją wolnorynkową ${ }^{14}$.

Po szóste, kluczowe jest uwzględnienie teorii integracji międzynarodowej i europejskiej, która sytuuje się w ,„połowie drogi” między krajowymi i międzynarodowymi relacjami. W tym obszarze należy wyjść od rozróżnienia między podejściem federalistycznym i konfederacyjnym oraz funkcjonalistycznym. Konieczne jest także uwzględnienie podejść takich jak instytucjonalne, liberalne i neoliberalne, regionalne, uniwersalne, wspólnotowe i sektorowe ${ }^{15}$. Głównym punktem odniesienia debat na temat integracji europejskiej jest federalizm. Oznacza on system rządów oparty na podziale władzy między poziom centralny (federalny) oraz niższe jednostki. W Unii Europejskiej miano federalistów uzyskali zwolennicy ściślejszej integracji kontynentu. Warto jednak podkreślić, że federalizm jest także przeciwieństwem centralizmu. Luźniejszą od federacji formę stanowi konfederacja. Konkurencyjną dla federalizmu koncepcją integracji jest jednak funkcjonalizm. Federaliści stawiają na tzw. high politics $\mathrm{i}$ instytucje, funkcjonaliści - na low politics i praktyczne rozwiązania ${ }^{16}$. Według podejścia funkcjonalistycznego każda sfera integracji wymaga różnych form (np. system transportu kolejowego powinien być rozwiązywany kontynentalnie, transport morski - międzykontynentalnie, a lotnictwo - globalnie $)^{17}$. Neofunkcjonalizm oparty jest na zasadzie „spill over” tj. rozlewania się integracji, w którym objęcie procesem integracji jednej sfery rozwiązanie występujących w niej problemów powoduje przeniesienie się integracji na kolejną, bliską sferę funkcjonowania społeczeństw ${ }^{18}$. W odniesieniu do zasięgu integracji wyróżnia się regionalizm i uniwersalizm. Dominujący model integracji europejskiej określa się mianem podejścia wspólnotowego, które wydaje się być pragmatycznym stanowiskiem federalistów i obejmuje dominację gospodarki nad polityką oraz współistnienie form ponadnarodowych międzyrządowych ${ }^{19}$. Pewną alternatywą jest metoda elastyczna - obejmująca zasadę „opt-out”, „Europę a'la carte”, teorię koncentrycznych kręgów oraz koncepcje twardego rdzenia ${ }^{20}$. Zazwyczaj łączy się funkcjonalizm, uniwersalizm, liberalizm i tzw. integrację rynków z jednej strony oraz regionalizm, instytucjonalizm i tzw. integrację gospodarek z drugiej strony.

14 E. Hovden, E. Keene, The globalization of liberalism, New York 2002, s. 96; Ch. Hill, M. Smith, International relations and the European Union, Oxford-New York 2005, s. 19, 23, 28.

15 S. Miklaszewski, Historyczne i ekonomiczne podstawy integracji krajów Unii Europejskiej, Nowy Sącz 1999, s. 9-14.

16 Ch. Hill, M. Smith, International relations and the European Union, Oxford-New York 2005, s. 20.

17 L. Jesień, Wybór czy inercja. Traktat Amsterdamski w świetle teorii integracji europejskiej, Nowy Sącz 2000, s. 37.

18 Ibidem, s. 37.

19 Ibidem, s. 18 i 27.

20 Ibidem, s. 18 i 27. 
Po siódme, istotne jest rozważenie znaczenia geografii politycznej, w tym różnic politycznych i ekonomicznych między kulturą anglosaską i europejsko-kontynentalną, nadreńskim i anglosaskim modelem ekonomicznym ${ }^{21}$. Z geografią polityczną wiąże się także zróżnicowanie podejścia do integracji w zależności od wewnętrznych warunków w krajach członkowskich. Warto uwzględnić w tym zakresie Indeks Wolności Ekonomicznej oraz World Values Surveys ${ }^{22}$. Różnice między kulturą angloamerykańską i kontynentalną oraz odpowiednimi modelami ekonomicznymi są związane ze sobą oraz z omawianymi wcześniej podziałami geograficznymi liberalizmu, konsensusami ekonomicznymi oraz empiryzmem i racjonalizmem. Kluczowe dla tego podejścia liberałów do Konstytucji znaczenie geografii politycznej polega na tym, że w każdym kraju liberałowie mogą uzależniać swój stosunek do UE od tego, czy bliższa integracja wzmacnia wolność ekonomiczną i osobistą obywateli danego kraju. Oznacza to np., że dla większości krajów postkomunistycznych integracja europejska powoduje ugruntowanie reform demokratyczno-rynkowych. UE może oznaczać też większą gwarancję stabilności liberalnego systemu politycznego - np. dla Włoch oraz większy poziom wolności ekonomicznej - np. dla Francji. Z kolei dla brytyjskich liberałów UE, a zwłaszcza brukselska centralizacja może oznaczać zarówno ograniczenie wolności ekonomicznej, jak i stabilizacji politycznej.

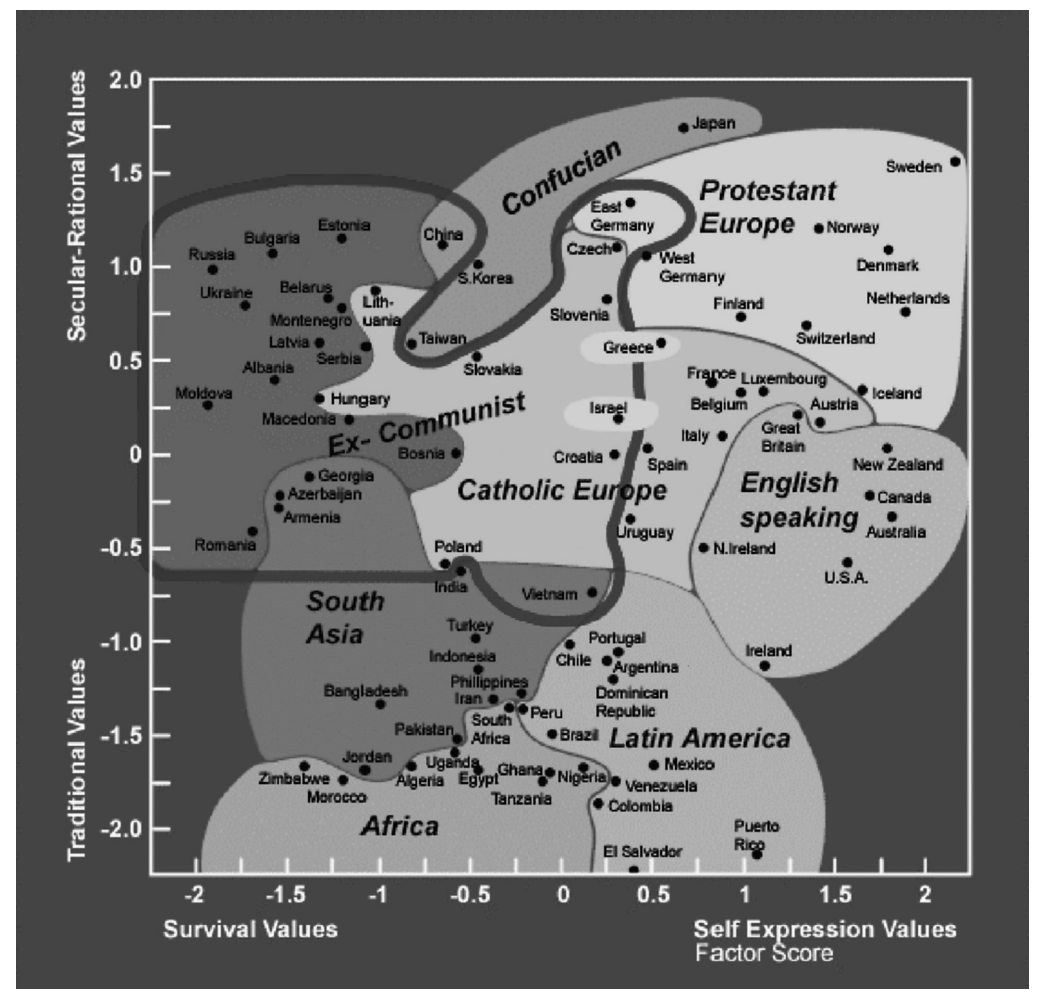

Źródło: World Values Surveys, www.worldvaluessurvey.org.

21 J. Szomburg, Jaki kapitalizm, „Przegląd Polityczny”, numer specjalny, Gdańsk 1993, s. 3.

22 www.heritage.org/index; www.worldvaluessurvey.org. 


\section{DISTRIBUTION OF ECONOMIC FREEDOM}

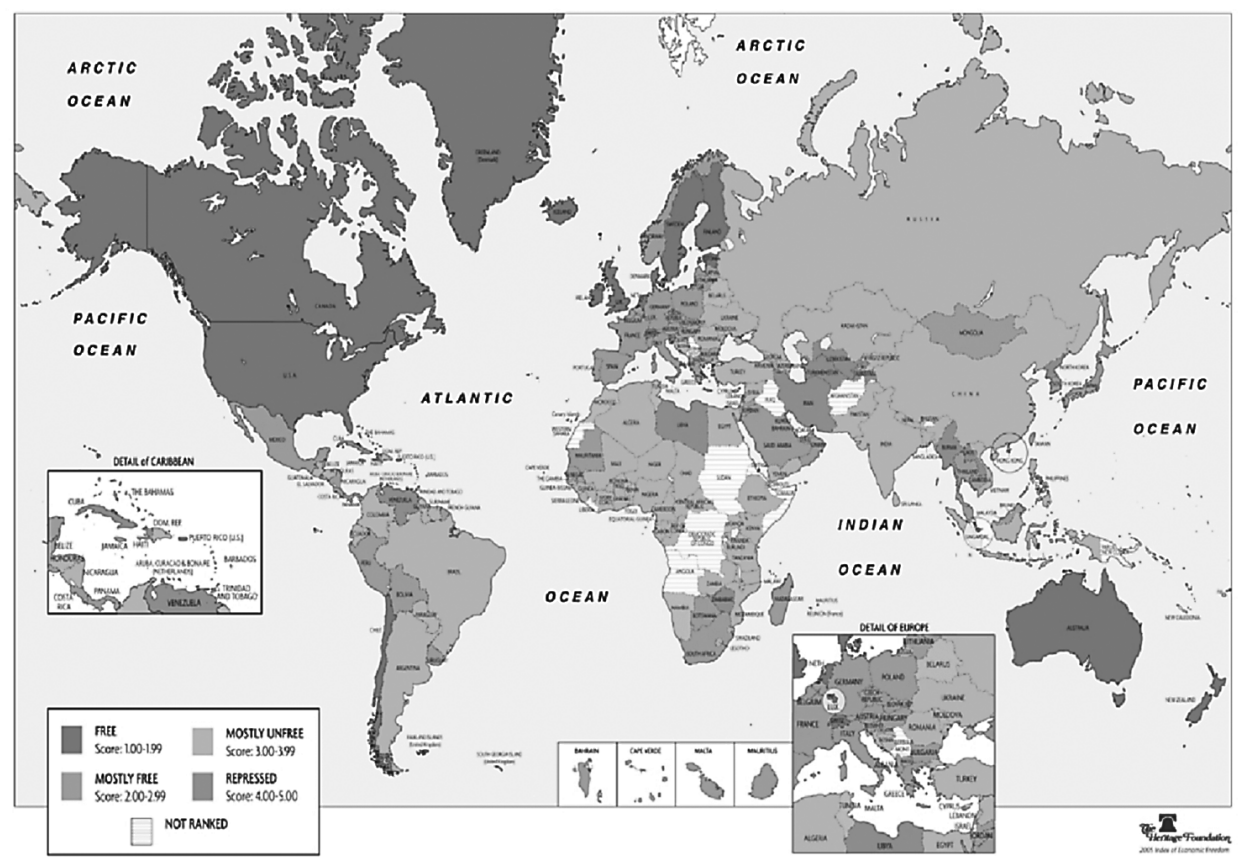

Źródlo: Heritage Foundation, www.heritage.org/index.

Po ósme, należy wyróżnić polityczne i ekonomiczne relacje międzynarodowe, które różnią się znaczeniem państwa i jednostki oraz tzw. high i low politics ${ }^{23}$. Współpraca ekonomiczna była ideałem początków amerykańskiej polityki zagranicznej i zdaje się oddawać inicjatywę jednostkom oraz podmiotom gospodarczym ${ }^{24}$. Współpraca polityczna stawia na nacisk na państwa. $Z$ tego punktu widzenia współpraca ekonomiczna może być zarówno pożądana przez liberałów, jak i realizowana przez UE. Warto jednak pamiętać o tym, że część liberałów widzi właśnie potrzebę współpracy politycznej, a w obszarze ekonomicznym pozostawienie po prostu wolnego rynku ${ }^{25}$ - współpraca ekonomiczna może także oznaczać harmonizację i standaryzację, wobec której liberałowie często pozostają sceptyczni.

${ }^{23}$ Ch. Hill, M. Smith, International relations and the European Union, Oxford-New York 2005, s. 20 .

24 A. de Tocqueville, O demokracji w Ameryce, Kraków 1996, t. I, s. 232-240. Jest to jedna z liberalnych recept na politykę zagraniczną. Może ona być wzorcem dla zwolenników wolnorynkowej metody integracji międzynarodowej.

25 F. A. von Hayek, Droga do zniewolenia, Kraków 1996, s. 233. Pozornie pogląd ten jest przeciwny przypisywanym liberałom tendencjom do czysto ekonomicznego traktowania procesu integracji. W rzeczywistości jednak Hayek sprzeciwia się międzynarodowej biurokracji gospodarczej, pozostając gorącym zwolennikiem integracji rynków. 


\section{Projekty Konstytucji Europejskiej i stanowiska liberałów}

Projekt Traktatu ustanawiającego „Konstytucję dla Europy” tworzy jedną Unię Europejską, zastępując dotychczasowe Wspólnoty i Unię i kolejne Traktaty oraz łącząc jej filary (choć pozostawiając specyficzne procedury w sprawach zagranicznych i bezpieczeństwa) i przyznaje UE osobowość prawną ${ }^{26}$. Konstytucja pozostaje jednak traktatem międzynarodowym. Projekt zawiera Kartę Praw Podstawowych oraz zasadę podziału władzy i uproszczenia prawa. Konstytucja porządkuje kompetencje Rady, Komisji i Parlamentu i rozszerza procedurę współdecydowania. Projekt tworzy funkcję Ministra Spraw Zagranicznych UE, powoływanego przez Radę Europejską w porozumieniu z szefem Komisji. Rada Europejska staje się pełnoprawną instytucją i powołuje swojego Przewodniczącego. Do 2014 roku w skład Komisji będą wchodzić przedstawiciele wszystkich państw, a następnie 2/3 państw na zasadzie rotacji. Większość kwalifikowana wynosi $55 \%$ państw reprezentujących $65 \%$ obywateli. Mniejszość blokująca obejmuje 4 państwa. Parlament dokonuje wyboru szefa Komisji na wniosek Rady (działającej większością kwalifikowaną) i zatwierdza skład Komisji. Rada Europejska dostarcza politycznych kierunków Unii, ale nie jest legislatywą. Konstytucja rozszerza kompetencje Europejskiego Trybunału Sprawiedliwości. Konstytucja nie wprowadza wielu zmian do polityk UE, z wyjątkiem akcentu na tworzenie obszaru wolności, bezpieczeństwa i sprawiedliwości w zakresie spraw wewnętrznych i wymiaru sprawiedliwości. Polityka azylowa i imigracyjna ma być prowadzona przez Unię wspólnie z państwami członkowskimi zgodnie z zasadą subsydiarności. Wzmacnia się współpracę sądową w sprawach kryminalnych. Projekt wprowadza solidarność między państwami w wypadku klęsk żywiołowych lub aktów terrorystycznych. Projekt wyróżnia kompetencje wyłączne UE, kompetencje dzielone z państwami członkowskimi i te, gdzie UE może podjąć działania wspomagające. Projekt zawiera zasady subsydiarności (monitorowanej także przez parlamenty narodowe) i proporcjonalności oraz obowiązek implementacji prawa przez państwa. Konstytucja także pozwala na podejmowanie działań przez UE dla realizacji swoich zapisów, a nie tylko rynku wewnętrznego. Generalnie projekt rozwija zakres obowiązywania procedur większości kwalifikowanej i współdecydowania. Większość kwalifikowana jest regułą, z wyjątkami w obszarze podatków i część postanowień Wspólnej Polityki Zagranicznej i Bezpieczeństwa oraz polityki społecznej. Rada może jednogłośnie rozszerzyć zasadę większości kwalifikowanej, choć może to być zablokowane przez któryś z parlamentów narodowych. Projekt akcentuje także zasady demokracji, przejrzystości i kontroli obywatelskiej, obejmujące m.in. inicjatywę obywatelską, otwartość posiedzeń Rady i wzmocnienie roli parlamentów narodowych.

Grupa Porozumienia Liberałów i Demokratów dla Europy (ALDE) powstała po ostatnich wyborach do Parlamentu Europejskiego w 2004 roku, łącząc dotychczasową frakcję liberalną oraz m.in. włoskich i francuskich deputowanych wcześniej współpracu-

${ }^{26}$ The European Commision, Summary of the Constitutional Treaty; European Parliament Delegation To The Convention, Summary of the Constitution adopted by the European Council; http://europa.eu/constitution/index_en.htm. Poniższy krótki opis projektu Konwentu opiera się na tych dwóch dokumentach. 
jących z chrześcijańskimi demokratami. ALDE prezentuje jednoznacznie proeuropejski program, zasadniczo popierając główny nurt integracji. Liberałowie zdecydowanie popierają projekt Konstytucji dla Europy, rozszerzenie UE, Wspólną Politykę Zagraniczną i Bezpieczeństwa, Euro, politykę strukturalną. ALDE domaga się większej otwartości, demokracji i przejrzystości w UE oraz ochrony wolności obywatelskich. Liberałowie akcentują rolę edukacji i nauki, ochrony środowiska. ALDE popiera reformę, ale nie likwidację Wspólnej Polityki Rolnej. Liberałowie opowiadają się za pomocą dla krajów rozwijających się, ale także otwarciem dla nich rynków ${ }^{27}$. Zdaniem ALDE, Konstytucja wzmacnia legitymizację, demokratyczność i efektywność UE oraz wyjaśnia i redefiniuje cele, wartości i zasady UE. Liberałowie popierają zarówno wzmocnienie pozycji Parlamentu Europejskiego, jak i legislatur narodowych w Konstytucji. ALDE zwraca uwagę na większy wpływ Parlamentu na budżet i Komisję Europejską. Liberałowie akcentują większą przejrzystość Rady dla obywateli. Zdaniem ALDE Konstytucja wzmacnia rolę obywateli, głównie poprzez Kartę Praw Podstawowych oraz obywatelską inicjatywę ustawodawczą. Liberałowie akcentują możliwość wykorzystania Konstytucji do lepszej pozycji UE na poziomie międzynarodowym, poprzez powołanie Ministra Spraw Zagranicznych oraz wprowadzenie zasady solidarności w przypadku klęsk żywiołowych lub ataków terrorystycznych ${ }^{28}$.

W głównym nurcie eurosceptycyzmu występuje przede wszystkim wizja „Europy Narodów". Jej zwolennicy sprzeciwiają się dalszej integracji politycznej, symbolizowanej przez wzrost roli Parlamentu i Komisji oraz wspólną politykę zagraniczną. Richard Cottrel wskazuje jednak na trzy kolejne osi sporu w debacie europejskiej: pierwszą, między zwolennikami federacji i współpracy państw narodowych, drugą, między liberałami ekonomicznymi a socjalistami i wreszcie trzecią między zwolennikami i przeciwnikami bliższej współpracy z USA $^{29}$. Dwa środowiska liberalne przygotowały konkurencyjne projekty Konstytucji. Pierwszy został przedstawiony przez londyński tygodnik „The Economist”, drugi jest wynikiem prac Europejskiej Grupy Konstytucyjnej.

Projekt „Economista” ${ }^{30}$ określa wolność, demokrację i rządy prawa jako fundamenty Unii oraz akcentuje zasadę subsydiarności i przewiduje obywatelstwo europejskie. Unia i państwa członkowskie mają szanować prawa człowieka, w tym (ale nie tylko) zapisy Europejskiej Konwencji Praw Człowieka oraz zasady prawa państw europejskich. Projekt akcentuje zasadę, że władza niedelegowana do UE należy do państw członkowskich. „Economist” proponuje, aby językami oficjalnymi UE były angielski, francuski i niemiecki. Projekt przewiduje istnienie następujących instytucji: Rady Europejskiej, Parlamentu, Rady Narodów, Rady Ministrów, Komisji, Banku Centralnego oraz Trybunałów Sprawiedliwości i Audytorów. Parlament miałby liczyć nie więcej niż 100 osób, wybieranych w wyborach powszechnych. PE mógłby debatować, weto-

\footnotetext{
27 Ten point plan of the ALDE Group, http://www.alde.eu/index.php

28 Andrew Duff Spokesperson of the ALDE Group on Constitutional Affairs, 10 Reasons for supporting the Constitution, http://www.alde.eu/index.php?id=79

29 R. Cottrell, The EU Constitution, Many Risks, Few Rewards, http://www.aei.org/publications/pubID.20684/pub detail.asp.

${ }^{30}$ A Constitution For The European Union, „The Economist”, http://www.aei.org/publications/pubID.20684/pub_detail.asp.
} 
wać i poprawiać legislację europejską. Nowoutworzona Rada Narodów skupiałaby reprezentantów parlamentów narodowych i miała charakter rady konstytucyjnej, zwierzchniej nad Europejskim Trybunałem Sprawiedliwości, mogącej zablokować legislację. Rada Ministrów stanowiłaby legislaturę UE i podejmowała decyzje jednomyślnie w przypadkach określonych przez traktaty oraz ,podwójną większością” krajów i ludności w innych sytuacjach. Komisja pełniłaby rolę Sekretariatu Unii oraz składała się z przewodniczącego oraz 12 członków. Posiadałaby prawo inicjatywy, pod kierunkiem Rady Europejskiej lub na wniosek Parlamentu. W dziedzinie polityk projekt Konstytucji przewiduje m.in. zakaz nakładania podatków przez Unię, zasady swobodnego przepływu osób, towarów i usług, dobrowolną Unię Walutową, wspólną politykę imigracyjną i azylową oraz funkcję wysokiego przedstawiciela UE ds. zagranicznych i obronnych, reprezentującego Unię w sprawach jednomyślnie uzgodnionych przez Radę Ministrów. Projekt „Economista” przewiduje bliższą współpracę grup państw, zasady przyjmowania członków, możliwość pozbawienia głosu kraju, który narusza podstawowe zasady UE oraz wystapienie z Unii, a także możliwość zwrócenia kompetencji od Unii do państw członkowskich.

Wizję liberalnej alternatywy konstytucyjnej najbardziej kompleksowo prezentuje jednak niemiecki polityk Otto Graf Lambsdorff w wykładzie „Europa i Konstytucja Wolności” dla Europejskiej Grupy Konstytucyjnej (EGK) ${ }^{31}$. Lambsdorff zauważa, że Konstytucja, regulująca zasady polityczne, nie powinna być pisana przez aktualnych polityków, co miało miejsce w przypadku Konwentu Europejskiego. Zdaniem Lambsdorffa, aktualnie jedyna opozycja wobec Konstytucji (a zatem także dominującego nurtu aktualnej integracji) pochodzi ze skrajnej prawicy. To dodatkowo pogarsza sprawe, dyskredytując także słuszny sceptycyzm i zwracając dyskusję w złym kierunku. Najgorszą alternatywą dla aktualnego kursu integracji jest powrót do nacjonalizmu i porządku sprzed rozpoczęcia procesu integracji. Lamsdorff prezentuje alternatywę „liberalnego konstytucjonalizmu”, tworzoną przez Europejską Grupę Konstytucyjną. Jest to wizja Europy opartej o zasadę decentralizacji, subsydiarności i konkurencyjnego federalizmu. Lamsdorff przypomina zasadniczą tezę liberałów, że społeczeństwo stawiające wybór indywidualny ponad kolektywny odnosi większy sukces, nie tylko w sferze ekonomicznej. Ojcowie Europy byli tego świadomi, o czym świadczy kluczowa rola „czterech wolności” w Traktacie Rzymskim. Jednak po latach w Unii Europejskiej sfera polityczna rozpoczęła dominować nad wolnością jednostki, o czym świadczy poziom regulacji, protekcjonizmu i redystrybucji w UE. Lamsdorff zaznacza, że o ile 50 lat temu uzasadnione było przyjmowanie wszystkich inicjatyw europejskich jako pozytywnych, dzisiaj nie można zakładać, że prawo jest dobre tylko dlatego, że jest europejskie. Przeregulowanie Europy powoduje krytykę, która zresztą bywa przesadzona, bo Wspólnoty osiagnęły wiele sukcesów w dziedzinie liberalizacji. Co ciekawe Lambsdorff zaznacza, że Niemcy nie mogą służyć jako dobry przykład dla Unii, ponieważ ich federalizm ma charakter centralistyczny i niekonkurencyjny. Lamsdorff ostrzega także, że przyznawanie nowych kompetencji Parlamentowi Europejskiemu nie może być postrzegane jako rozwiązanie wszystkich problemów UE. Deficyt demokracji można

31 Otto Graf Lamsdorff, Europe and the Constitution of Liberty, 2002, http://www.fnst.org/webcom/show_page.php/_c-1206/_nr-1/_lkm-1870/i.html. 
zmniejszać poprzez przekazanie prawa veta z Rady UE do parlamentów narodowych. Jego zdaniem sztandarowa zasada subsydiarności nie jest wystarczająco stosowana. Lambsdorff podkreśla, że winę za tę sytuację ponosi nie tylko „Bruksela”, ale także politycy w krajach członkowskich.

Europejska Grupa Konstytucyjna (EGK) zaprezentowała pierwszą wersję projektu Konstytucji Europejskiej już w 1993 roku $^{32}$. EGK uznało za kluczowe: zbliżenie UE do obywateli, uznanie zróżnicowania w Europie, wzmocnienie udziału obywateli w integracji oraz ustalenie ograniczeń władzy instytucji europejskich. Zadaniem Grupy było przygotowanie wizji europejskiej unii politycznej alternatywnej wobec centralizmu i opartej na indywidualnej wolności. EGK opowiadało się za wprowadzeniem Konstytucji ze względu na sześć zasadniczych przyczyn: przejrzystość UE, ochronę wolności indywidualnej, ustalenie procedur podejmowania decyzji, określenie zadań instytucji, obronę zasad rynkowych oraz poszerzenie UE. EGK zaproponowało włączenie wolności indywidualnych i obywatelskich oraz rynkowych do Konstytucji. Grupa postuluje silniejsze przestrzeganie zasady subsydiarności i możliwość „Zwrócenia” kompetencji z Unii do państw członkowskich. EGK postawiła postulat sprecyzowania zasad przystapienia do Unii (prawa człowieka, demokracja, gospodarka rynkowa, wolny handel) oraz prawo opuszczenia UE. Wg założeń projektu, zasada jednomyślności zostałaby ograniczona do spraw konstytucyjnych, natomiast wprowadzono by dodatkowo zasadę większości wysokokwalifikowanej i zwykłej kwalifikowanej. Wśród priorytetów projektu były także ścisłe ograniczenia budżetowe. W odniesieniu do instytucji europejskich, Grupa postulowała, aby rolę głównych organów politycznych pełniły Rada Ministrów i Rada Europejska, natomiast Komisja powinna być sprowadzona do roli ciała administracyjnego. Parlament Europejski powinien być poszerzony o drugą izbę, składającą się z reprezentantów parlamentów narodowych. EGK proponowało także stworzenie dodatkowego sądu unijnego, składającego się z sędziów narodowych, który pilnowałby zasady subsydiarności i strzegł Unię przed centralizacją.

Grupa zaproponowała dziesięć zasad konstytucyjnych: oddolność władzy w Unii, jasna definicja celów Unii (uwzględnienie tego, że część celów może być realizowanych przez państwa, a część nawet w szerszych ramach niż Unia, jak np. obrona), różne metody współpracy w Unii, silniejsze zasady rynkowe (które lepiej służą potrzebom jednostek niż mechanizmy polityczne), większe otwarcie na zewnętrzną wymianę towarów, usług i kapitału, ewolucyjne podejście do wspólnej waluty, konstytucyjne ograniczenie centralizacji, zasada „checks and balance” (obejmująca podział władzy i wzmocnienie państw), możliwość zwrotu kompetencji z Unii do państw oraz obronę państw znajdujących się w mniejszości (poprzez zasadę opt-out, prawo secesji).

W 2004 roku Grupa przedstawiła swoją ocenę projektu Konwentu Europejskiego, odnotowując kilka jego zalet, ale podkreślając, że jego bilans jest negatywny ${ }^{33}$. Zakaz

32 The Constitution Of The European Union, A Proposal for a European Constitution (Summary of Main Features). Extract from Report by the European Constitutional Group, http://www.fnst.org/webcom/show page.php/ c-1203/ nr-1/ lkm-1868/i.html.

33 European Constitutional Group, A Critique of the Constitutional Treaty, Adopted by the Intergovernmental Conference, 2004; European Constitutional Group, An Appraisal of the Constitutional Treaty Proposed by the European Convention, 2003, http://www.fnst.org/webcom/show_page.php/_c-1203/_nr-1/_lkm-1868/i.html. 
kwestionowania acquis communitaire oraz dążenie do „coraz bliższej integracji” w Preambule narzuca obywatelom kierunek integracji. Kompetencje Unii nie powinny dotyczyć wszystkich celów wspólnych dla państw (art. I-1), bo także takie cele mogą być realizowane lepiej na niższym poziomie. Solidarność i spójność (art. I-3) powinny być pozostawione niższym poziomom, a prawa człowieka są lepiej chronione przez Konwencję Europejską. Z kolei Karta Praw Podstawowych zawiera nie tylko wolności osobiste, ale także pole do działalności regulacyjnej rządu (głównie w dziedzinie tzw. praw ekonomicznych i socjalnych). Zasada subsydiarności (art. I-9 i Protokół) jest lepiej sformułowana, ale brakuje regulacji dotyczącej zabezpieczenia jej wdrażania (Europejski Trybunał Sprawiedliwości wykazuje tendencje do centralizacji, a parlamenty narodowe mają zbyt mało czasu na wnoszenie zastrzeżeń, które i tak mogą być odrzucone przez Komisje). Kwestie polityki zagranicznej (art. I-11-15) powinny być obiektem wzajemnej współpracy, a nie instytucji UE. Artykuł I-17 rozciaga kompetencje UE z „wprowadzania wspólnego rynku” na „,ele Konstytucji”. Artykuł I-19 rozszerza władze Parlamentu, bez zapobiegnięcia jego skłonnościom centralizacyjnym. EGK chwali natomiast wprowadzenie funkcji Prezydenta Rady Europejskiej (I-21). W odniesieniu do zmniejszenia kryteriów większości kwalifikowanej w Radzie (art. I-24), Grupa dostrzega pozytywne konsekwencje w niektórych dziedzinach, ale podkreśla dramatyczne skutki w innych, np. rynku pracy, które nie powinny być kompetencjami centralnymi. Kraje przeregulowane mogą zgodnie ze strategią podwyższania kosztów konkurencji, zwiększać regulacje w krajach bardziej liberalnych. Komisja nie powinna mieć monopolu inicjatywy ustawodawczej (art. I-25), bo w ten sposób może blokować inicjatywy decentralizacyjne, inicjatywa ta powinna przypadać Parlamentowi i Radzie. Grupa krytykuje brak zabezpieczeń niezależności Europejskiego Banku Centralnego i banków państw oraz brak zdefiniowania stabilności cen. EGK pochwala natomiast wprowadzenie procedury wystapienia z Unii. Cześś III rozszerza kompetencje Unii na wiele niepotrzebnych zdaniem Grupy obszarów takich jak koordynacja polityki społecznej i zdrowotnej, badania i technologie, energię czy sport oraz likwiduje zasadę jednomyślności w odniesieniu do 47 obszarów, głównie gospodarczych. Art. III-262 nie wprowadza wystarczających zabezpieczeń przed centralizmem Europejskiego Trybunału Sprawiedliwości. Warto jednak zaznaczyć, że część propozycji EGK, formułowanych od połowy lat 90-tych, zostało przyjętych przez Konwent, co najmniej częściowo - np. możliwość wystąpienia z UE i (minimalne) wzmocnienie parlamentów narodowych.

Po przedstawieniu projektu Konwentu Europejskiego, Europejska Grupa Konstytucyjna przygotowała swoje zmiany do projektu i wersję Konstytucji uwzględniającą te zmiany, która jest ostateczną propozycją Grupy i podstawą naszego porównania ${ }^{34}$. Grupa proponuje skrócenie listy wartości Unii (kosztem wartości społeczno-ekonomicznych) oraz dodanie do celów wolności rynkowych. Poprawki ograniczają prawa podstawowe do politycznych, rezygnując ze społeczno-ekonomicznych. EGK nie

34 Treaty Establishing A Constitution For Europe, Annotated Version For ECG Discussion As Of April 2006; A Proposal For A Revised Constitutional Treaty, April 2006; A Basic „Constitutional” Treaty For The European Union - With Comments, June 2003, http://www.fnst.org/webcom/show_page.php/_c-1203/_nr-1/_lkm-1868/i.html 
uwzględnia również symboli unijnych, które jej zdaniem upodobniają UE do państwa. Projekt Grupy zawiera ścisłe ograniczenia dotyczące kompetencji Unii i zabezpieczające subsydiarność, zwłaszcza w przypadku poważnych konsekwencji finansowych. EGK podkreśla także zasadę przyznania, zgodnie z którą Unia działa tylko zgodnie z wyraźnie przyznanymi jej kompetencjami. EGK proponuje wyraźne wyróżnienie nielicznych obszarów wyłącznej kompetencji i zarazem nadrzędności prawa Unii (unia celna, polityka monetarna w strefie Euro, wspólna polityka handlowa), również niewielu obszarów kompetencji dzielonej (rynek wewnętrzny i konkurencja, rybołówstwo oraz kwestie środowiska, gdy jedno państwo szkodzi drugiemu), w której konflikt praw powinien być rozstrzygany przez specjalny sąd oraz największego obszaru wyłącznej kompetencji państw, gdzie ich prawo jest nadrzędne (obejmujących wszystkie inne obszary, w szczególności szeroko rozumianą politykę społeczną i podatki). Polityka gospodarcza oraz polityka zagraniczna (a także w pewnym zakresie pomoc rozwojowa) powinny być przedmiotem wzajemnego zainteresowania.

W odniesieniu do instytucji europejskich, Grupa proponuje podkreślenie zasad demokracji i podziału władzy. EGK przedstawia regulacje wprowadzające dwie izby Parlamentu. W pierwszej, wybieranej bezpośrednio na zasadzie degresywnej proporcjonalności, liczącej nie więcej niż 500 osób, poszczególne państwa miałyby od 2 do 50 reprezentantów. Pierwsza izba miałaby prawo inicjatywy ustawodawczej, zgłaszanej do Rady oraz prawo poprawiania lub blokowania ustawodawstwa. Druga izba, składająca się z przedstawicieli parlamentów narodowych, mogłaby blokować legislację niezgodną z Konstytucją a głównie zasadami subsydiarności i proporcjonalności. Rada Europejska, oprócz określania generalnych kierunków politycznych i priorytetów, posiadałaby wyłączne prawo proponowania aktów legislacyjnych na wniosek Parlamentu. Rada wybierałaby swojego przewodniczącego. Rada Unii Europejskiej wspólnie z Komisja, przygotowywałaby akty prawne i budżetowe, propozycje wnoszone do Parlamentu oraz określała politykę i pełniła funkcje koordynacyjne. Rada działałaby na zasadzie kwalifikowanej większości z wyłączeniem sytuacji, w których Konstytucja mówi inaczej. Kwalifikowana większość wynosiłaby 2/3 państw i ludności Unii, z mniejszością blokującą 4 państw. Komisja Europejska pełniłaby funkcje wykonawcze pod kierunkiem Rady Europejskiej, tracąc prawo inicjatywy ustawodawczej. Komisja nie mogłaby pracować dłużej niż dwie kadencje, wybierałaby swojego przewodniczącego, a jej członkowie mogliby być odwołani przez Radę Europejską. Europejski Trybunał Sprawiedliwości nie obejmowałby spraw praw człowieka (za które odpowiada Europejski Trybunał Praw Człowieka) oraz sporów kompetencyjnych między Unia, a państwami, którymi zajmowałby się Court of Review powoływany przez sądy najwyższe państw członkowskich. Pierwsza izba nie powinna blokować ustawodawstwa upraszczającego lub likwidującego regulacje, o ile ustawodawstwo to zyska poparcie drugiej izby.

Projekt Grupy zawiera także ograniczenia europejskich rozporządzeń delegowanych. EGK proponuje, aby „bliska współpraca” państw członkowskich odbywała się poza procedurami Unii, co uniemożliwi tworzenie kategorii państw. Projekt Grupy wprowadza poważne ograniczenia budżetowe Unii - wzrost wydatków Unii powyżej ram finansowych wymagałby akceptacji wyborców w państwach - tzw. płatnikach netto. Ramy finansowe powinny być uzgadniane jednogłośnie przez wszystkie państwa 
i akceptowane przez ich parlamenty. Konstytucja zakazywałaby też wprowadzenia podatków europejskich (aby zapobiec tworzeniu kartelu podatkowego państw przeciw wolności zmiany miejsca zamieszkania z przyczyn podatkowych przez obywateli). Utrata pewnych praw państwa w Unii wynikałaby nie z decyzji instytucji europejskich, ale orzeczenia Europejskiego Trybunału Praw Człowieka. Każde państwo mogłoby podjąć decyzję o wystąpieniu z Unii, co nie powinno jednak likwidować obowiązywania „czterech wolności” UE. Propozycja uwzględnia tylko część Karty Praw Podstawowych, tzn. wolności (myśli, sumienia, religii, wypowiedzi, informacji, zgromadzeń, stowarzyszeń, sztuki i nauki), prawo do własności, równość wobec prawa, różnorodność kulturalna, religijna i językowa oraz prawa wyborcze w wyborach europejskich i samorządowych, prawo do dobrej administracji, w tym dostępu do dokumentów instytucji i ochrony danych osobowych, wolność przemieszczania się, ochrony dyplomatycznej i konsularnej. Ostatnia część Konstytucji, obejmująca polityki Unii, uwzględnia tylko rynek wewnętrzny, zasady konkurencji, politykę gospodarczą i ochronę środowiska oraz polityki zewnętrzne.

Konkludując, propozycja Europejskiej Grupy Konstytucyjnej (oraz „Economista”) obejmuje cztery zasadnicze obszary - polityczny, instytucjonalny, tematyczny i finansowy. W sprawach politycznych, EGK proponuje „niecentralistyczną unię polityczną”, „konkurencyjny federalizm” $i$, ,iberalny konstytucjonalizm”. Zabezpiecza zasadę subsydiarności i wprowadza możliwość zwrotu kompetencji na niższy poziom. Przekreśla zasady, że nie każde prawo europejskie jest dobre i że jedynym sposobem zbliżenia Unii do obywateli jest wzmocnienie Parlamentu. Przeciwstawia się regulacji, redystrybucji i protekcjonizmowi. Wzmacnia zasady rynkowe i rezygnuje z tzw. praw socjalnych i ekonomicznych. W obszarze instytucjonalnym oznacza osłabienie roli Komisji na rzecz Rady, przekazanie inicjatywy Parlamentowi i Radzie Europejskiej, wprowadzenie drugiej izby oraz drugiego Trybunału i - zgodnie z propozycją Konwentu - powołanie prezydenta Rady Europejskiej. Wprowadza funkcję Ministra Spraw Zagranicznych, ale pozostawia jednomyślny sposób podejmowania decyzji w sprawach zagranicznych. Odnośnie zakresu działania Unii, EGK postuluje znaczne ograniczenie obszarów wyłącznej kompetencji UE obszarze kompetencji dzielonej na rzecz państw członkowskich. W obszarze finansowym, proponuje ścisłe ograniczenia wydatków.

Patrząc na projekt EGK przez pryzmat idei „niecentralistycznej unii politycznej”, „konkurencyjnego federalizmu” i „liberalnego konstytucjonalizmu” można jednak zgłosić co najmniej dwie wątpliwości. Po pierwsze, z tych ideałów zdaje się wynikać przypisanie władzom unii federalnej kompetencji w dziedzinie polityki zagranicznej i obronnej. Współgra z tym wsparcie EGK dla stworzenia funkcji Ministra Spraw Zagranicznych, a także Przewodniczącego Rady, ale nie uznanie polityki zagranicznej za przedmiot „wzajemnego zainteresowania” i przyjęcie procedury jednomyślności w odniesieniu do niej. Z kolei, jeśli chodzi o obronność, można by dowodzić, że UE nie musi się nią zajmować ze względu na udział większości jej członków w szerszym porozumieniu - NATO. Wydaje się, że także brak wspólnej polityki zagranicznej wynika z faktu, że część krajów UE jest nie mniej związana z USA niż z resztą Europy. Po drugie, wątpliwości budzi konstrukcja instytucjonalna EGK. Rada Europejska i Rada UE łączą kompetencje prawodawcze i wykonawcze. Funkcję drugiej izby parlamentu, reprezentującej części składowe (odpowiednikiem Senatu USA czy Bundesratu) zdają 
się dzielić druga izba PE, Rada Europejska i Rada UE. Sprawia to wrażenie nadmiaru instytucji reprezentujących narody oraz nadmiernego wpływu narodowej władzy wykonawczej na wspólnotową władzę prawodawczą.

\section{Alternatywny model spektrum politycznego Unii Europejskiej}

Stanowiska „Economista” i Europejskiej Grupy Konstytucyjnej pokazują, że dotychczasowy podział spektrum politycznego UE na zwolenników ściślejszej integracji i jej przeciwników nie oddaje w pełni problemu. $\mathrm{W}$ odniesieniu do integracji europejskiej nie można już ograniczać się do pytania „czy?”, ale także zadawać pytanie ,jak?”. To ostatnie pytanie nie dotyczy tylko instytucji europejskich, ale także tego, jaki obszar wolności, zwłaszcza ekonomicznej, powinna pozostawiać Unia Europejska. Połączenie tendencji proeuropejskich z prosocjalnymi spycha ekonomicznych liberałów do obozu eurosceptycznego.

Ten artykuł dowodzi, że kluczowe znaczenie mają dwie (niezależne i krzyżujące się) linie podziału - między zwolenników i przeciwników bliższej integracji oraz sympatyków i oponentów wolnego rynku.

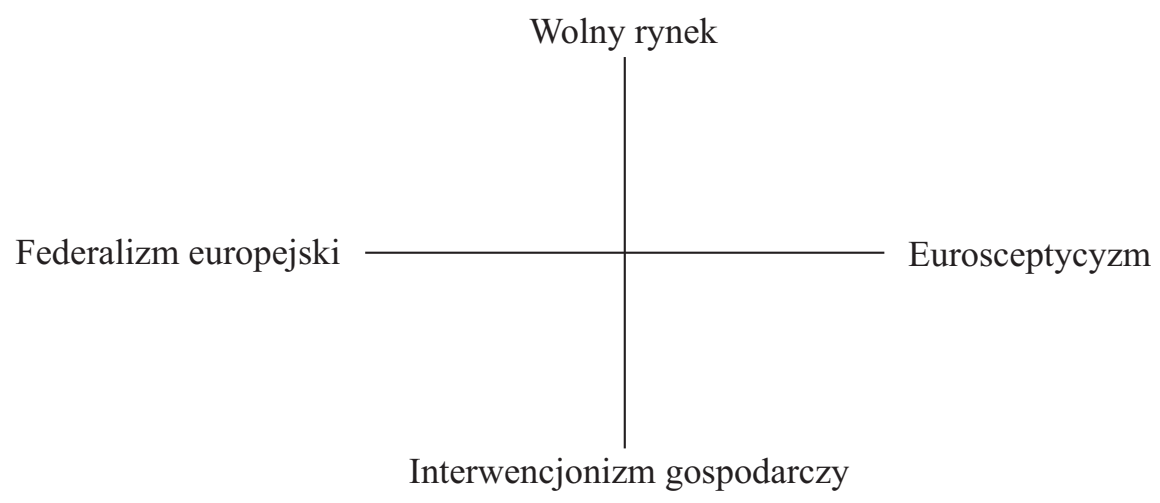

Mniejsze znaczenie ma stosunek do tzw. spraw światopoglądowych (i wolności osobistych), bo większość tych kwestii regulowana jest na poziomie narodowym (wyjątkiem od tej reguły był spór o odwołanie do Boga w Konstytucji). Nieco większe znaczenie może mieć stosunek do współpracy z USA, który jednak - w praktyce i co do zasady - jest zbliżony do linii zwolenników i przeciwników wolnego rynku.

Inspiracją tej tezy jest praca Davida Nolana, który zaproponował alternatywny model spektrum politycznego, na przykładzie USA ${ }^{35}$. Zamiast dotychczasowej linii prawica-lewica, Nolan przedstawił model dwóch krzyżujących się linii - wolności osobistej i ekonomicznej. W USA konserwatywna prawica łączy wsparcie dla wolności ekonomicznej i ograniczanie wolności osobistej. Lewica z kolei popiera wolność osobista i ogranicza wolność ekonomiczną. W modelu Nolana wskazana została opcja wsparcia (lub jego braku) dla obu wolności, tworząc przestrzeń dla pozycji klasycznie liberalnej

\footnotetext{
$35 \mathrm{http} / / / \mathrm{www}$.politopia.com/more politopia.htm.
} 
(libertariańskiej) i komunitarystycznej (populistycznej). Analogicznie, model proponowany w tym artykule może rozwiązywać problem spektrum politycznego Unii Europejskiej, dodatkowo skomplikowanego przez wpływ geografii politycznej na stosunek do integracji.

Kluczowe znaczenie należy przypisać geografii politycznej. W Wielkiej Brytanii zwolennicy wolnego rynku (głównie z Partii Konserwatywnej i klasycznie liberalnych think tanków) są zdeklarowanymi przeciwnikami UE. W Polsce zwolennicy wolnego rynku są równocześnie najmocniejszymi orędownikami integracji. Ta sytuacja może prowadzić do nieporozumień. Np. brytyjscy konserwatyści zamierzali stworzyć wspólną frakcję w Parlamencie Europejskim z polskim Prawem i Sprawiedliwością, ze względu na wspólny eurosceptycyzm, choć pierwsze ugrupowanie krytykuje UE za zbytni socjalizm, a drugie - za nadmierny liberalizm. Brytyjska liberalna Eurosceptyczka Margaret Thatcher jest z pewnością bliższa poglądom polskiego liberalnego euroentuzjasty Leszka Balcerowicza niż socjalnych eurosecptyków braci Kaczyńskich, lub np. francuskiego eurosceptyka Ch. De Gaulla.

Proponowany model obejmuje cztery podejścia, stanowiące kombinację federalizmu i eurosceptycyzmu oraz liberalizmu ekonomicznego i etatyzmu. Dominujący aktualnie nurt euroentuzjastów reprezentuje podejście socjalne. Można nazwać je federalizmem kooperacyjnym, rządowym czy też socjalistycznym. Jest związany z Partią Europejskich Socjalistów, ale posiada także wpływy wśród chadeckiej Europejskiej Partii Obywatelskiej. Najwybitniejszym reprezentantem tej opcji zdaje się być Jacques Delors. Opcja nacjonalistyczna łączy sceptycyzm wobec integracji europejskiej z socjalnym podejściem do gospodarki, czego przykładem jest obecny rząd Polski. Opcję liberalnego eurosceptycyzmu reprezentują brytyjscy konserwatyści oraz budowany przez nich Ruch na Rzecz Reformy Europejskiej. Liberałowie i chadecy w Parlamencie znajdują się na granicy rynkowego i socjalistycznego federalizmu. Europejska Grupa Konstytucyjna z kolei sytuuje się między federalistycznym i eurosceptycznym podejściem rynkowym. Narodowe frakcje w Parlamencie (Europa Narodów i Niepodległość i Demokracja) znajdują się w „centrum” podejścia eurosceptycznego.

Liberalni federaliści i eurosceptycy zgadzają się co do liberalizmu ekonomicznego, ale różnią w sprawach politycznych. Eurosceptycy popierają strefę wolnego handlu (lub unilateralistyczną liberalizację), ale sprzeciwiają się współpracy politycznej. Liberalni i narodowi eurosceptycy wspólnie sprzeciwiają się integracji politycznej Europy, ale różni ich podejście do gospodarki. Nacjonaliści popierają interwencjonizm państwowy, a liberałowie wolny rynek i handel międzynarodowy. Liberalni i socjalistyczni federaliści zgadzają się co do sensu istnienia władzy federacyjnej, ale różnią się co do jej kompetencji, zwłaszcza ekonomicznych. Socjalni federaliści chcą budować europejskie państwo dobrobytu, liberałowie - europejskie państwo minimum. Liberalny wspólny rynek w wizji socjalistów wymaga regulacji i harmonizacji. Co kluczowe, socjaliści poprzestają na rynku w Europie, stosując spore ograniczenia w handlu zagranicznym. Federaliści socjalni i nacjonaliści mają podobne zdania w sprawach ekonomicznych, ale różnią się tym, czy państwo dobrobytu ma istnieć na poziomie narodowym czy europejskim oraz czy Europie potrzebna jest współpraca polityczna.

Liberalny federalizm postulowałby swoiste ,państwo minimum” na poziomie europejskim. System instytucjonalny powinien opierać się na równowadze między repre- 
zentacją rządów i obywateli UE oraz podziale władzy. Kompetencje władz federalnych miałyby charakter szczególny (a państw - ogólny) i powinny modelowo obejmować sprawy zagraniczne, bezpieczeństwo zewnętrzne oraz koordynację spraw wewnętrznych i wymiaru sprawiedliwości. W sferze ekonomicznej, Unia opierałaby się na zasadach swobodnego przepływu towarów, usług, kapitału i ludzi oraz wolnego handlu międzynarodowego. Względem tego teoretycznego modelu, w przypadku Unii Europejskiej mamy do czynienia $\mathrm{z}$ komplikacją $\mathrm{w}$ dziedzinie polityki zagranicznej i obronnej. Komplikacja ta wynika z dwóch, powiązanych ze sobą przyczyn, co pokazuje projekt Europejskiej Grupy Konstytucyjnej. Po pierwsze, istnieje spora grupa, zbliżona do ,rynkowców”, która popiera wspólną obronę, ale na poziomie wyższym niż UE, tzn. w ramach NATO. Po drugie, grupa ta także uważa, że współpraca w sprawach zagranicznych powinna być rozszerzona na Stany Zjednoczone, a wprowadzenie Wspólnej Polityki Zagranicznej UE, choć w teorii sprzyjałoby konsolidacji Zachodu i dawało USA silnego partnera, w praktyce służyłoby konkurencji ze Stanami. Stąd też sprzeciw wobec Wspólnej Polityki Zagranicznej i Obronnej nie musi być wynikiem nacjonalizmu. Z globalnego punktu widzenia UE może więc nie sprawiać wrażenia dążenia do internacjonalizacji i globalizacji, ale regionalnego zamknięcia. Dodanie elementu globalnego w gospodarce i atlantyckiego w polityce oznacza, że wolnorynkowcy „przeskakują" socjalnych federalistów w internacjonalizmie, domagając się politycznej współpracy atlantyckiej i globalizacji ekonomicznej. Co prawda, w wymiarze politycznym, socjalni federaliści jeszcze raz „,przeskakują” wolnorynkowców, wspierając, z reguły, Organizację Narodów Zjednoczonych przeciw dominacji USA. 
